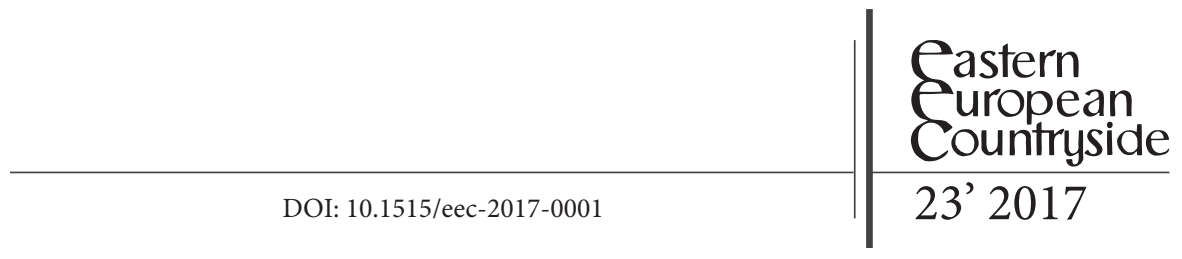

Krystyna Szafraniec, Paweł Szymborski, Krzysztof Wasielewski

\title{
Between the School and Labour Market. Rural Areas and Rural Youth in Poland, Romania and Russia ${ }^{1}$
}

\begin{abstract}
The article analyses the process of rural youth entering the labour market in selected post-communist countries (Poland, Romania and Russia). Based on different types of local (national) and international source data, similarities and differences are discussed between the analysed countries. The article focuses on transition from education to a satisfactory job, nowadays a very complex process that takes up nearly the entire third decade of young people's life. Although this process is just an external manifestation of general changes occurring in labour markets around the world, the experience of young people from post-communist countries in this area seems to be more traumatic than that of their peers in developed Western countries. Despite significant investments in education, it is difficult to deal with new challenges, particularly for the youth from rural areas. In all the analysed countries, chaotic career paths are typical of this population, and they are often based on temporary jobs, informal forms of employment or self-employment.
\end{abstract}

Keywords: School and social inequality, rural youth, labour market, postcommunist countries

1 The article was written as part of the following project funded by the National Science Centre (NCN) in Poland Młodzież w krajach post-komunistycznych. Potencjał innowacyjny, nowe konteksty, nowe problemy i nowe wyzwania (Youth in post-communist countries. Innovative potential, new contexts, new problems and new challenges), No UMO2013/08/M/HS6/00430. 


\section{Introduction}

In today's world, access to work (employment) has become one of the key factors which determine the quality of life, with all its social aspects, such as satisfaction and social tensions. At the same time, due to a variety of circumstances (civilisational changes, economic recession, global trends), work has become a scarce asset. Job deficits primarily affect younger generations, typically raised in the culture of consumerism. Successoriented and focused on personal well-being, they live a life-style which has significant individual and social implications. According to the ILO reports, the unemployment, economic activity and employment rates for many years have been better for adults than for the youth. In the light of the current legal regulations and employers' preferences, even the young people who have managed to enter the labour market cannot find a stable employment. The job offers addressed to them predominantly include variable, pluralistic forms of part-time and temporary employment. There are several reasons why this happens. First and foremost, it is caused by the volatile nature of postmodern capitalism, as well as by lack of compatibility between the educational offer and labour market requirements, which today are highly variable and amorphic. All these factors, further driven by unstable economic conditions, make satisfactory transition from education to labour market increasingly uncertain and risky. Nowadays this phenomenon is observed in both well-developed and developing countries, whereby the latter find it much more difficult to deal with it effectively.

The article focuses on post-communist countries which in many respects meet the definition criteria adopted for developing countries. Rurality is one of such features. Its demographic, economic and social aspects allow to identify the country's system, and thus determine its specific problems and challenges. In the article we ask questions about life strategies taken up by young people from rural areas in the selected post-communist countries. In particular, we are interested in the youth's transition from education to employment, a critical moment for their further independence in life, marked by a high level of difficulty and risk of failure. How does the rural youth do it? What are their transition paths and where is their place in the social structure enforced on them by the reality of their country's political tranformation? Do new life opportunities arise for young people as a result 
of structural changes in the economy, and if so, then what are they related to? What jobs and social position can young people expect to have under the changing economic conditions?

The source data used for the analysis has been obtained under an international project of nine post-communist countries in Europe and Asia. Based on the available sources of information (monographs, national and international reports, official national statistics), we offer a multi-faceted description of the situation of younger generations. In the project, we ask about the possible direction of systemic changes if these could be defined, on the one hand, by younger generations and their innovative resources (new competencies, aspirations, life priorities), and on the other hand, by the capacity and limitations of the system within which they have to function. A number of questions has also been raised regarding, but without limiting to, the specific nature of rural areas ${ }^{2}$. For the purposes of this article, we have decided to reduce the number of countries to be included in the analysis, focusing on those which allow to show the post-communist space as relatively homogeneous (post-Soviet block) on the one hand, while internally diversified, on the other hand. Eventually the following countries have been selected: Poland, Romania and Russia. While the demographic potential and thus percentage of rural population is similarly significant across all of these countries, they all have followed different paths in transforming their rural areas and agriculture. Their approach to structural changes, reforms and measures intended for this sector is different, just as is their vision of education and the role that it is to play in providing for social changes in the countryside.

\section{Rurality and agrarian character of the analysed countries}

One of the main challenges faced by post-communist countries at the beginning of their transformation process was to recompose their social structure, among others by launching new channels and mechanisms

2 The complete analysis may be found [in] K. Szafraniec, J. Domalewski, P. Szymborski, K. Wasielewski, M. Wernerowicz (2017). ME Generation in Post-collectivist Space. Dilemmas during the Time of Transition, Geneva: Peter Lang International Publishing House (forthcoming). 
providing for social mobility. Particularly significant problems arose when people started abandoning agriculture for other professions, which resulted in mass migrations. In most developed countries, major metamorphosis of rural areas and agriculture occurred already a long time ago ${ }^{3}$. Post-communist countries are delayed and considerably diversified in this respect. Upon joining the EU, Poland had the largest percentage of peasant farms, which by then had nearly disappeared from the rural landscape of Western Europe. Since that time Polish agriculture has undergone a dramatic transformation driven by a combination of specific economic, social and political factors; nevertheless, still many problems exist that need to be solved (Wilkin 2007: 177). The countryside and farmers have become the main beneficiaries of the EU Common Agricultural Policy, which has had a profound effect on the condition and image of Polish countryside (Knieć 2012: 132-151). Romania is one of the countries where agriculture continues to play a significant role in the economy. It also relies on the EU subsidies, but these are much smaller and are differently distributed, with large-scale agricultural holdings being the main beneficiaries ${ }^{4}$. Smaller farms, or the countryside in general, benefit from the EU funds to a significantly lesser degree, which further cements their traditional character. Major problems are experienced by Russian agriculture. As a result of reforms applying free market principles to its agroindustrial complexes, the number of agricultural enterprises (sovkhozes or state farms, and kolkhozes or collective farms) has dropped by $56 \%$ (half of which are nowadays unprofitable), while the countryside has turned into a place offering practically no life prospects and struggling with serious social problems (Mukhanova 2014). In each of these countries, agriculture generates only a minor percentage of the GDP - in Poland it is 3.3\%, slightly

3 Because of national differences in the characteristics that distinguish urban from rural areas, the distinction between the urban and rural population is not amenable to a single definition that would be applicable to all countries. National definitions are most commonly based on the size of locality. Population which is not urban is considered rural. http://stats.oecd.org/glossary/detail.asp?ID $=6342$.

4 In 2008-2013, the subsidies for agricultural holdings reached EUR 6,896 million for Romania and EUR 14,808 million for Poland (from: http://farmsubsidy.openspending. org). From 1 May 2004 to 30 November 2015, the total of EUR 122.45 billion of the EU funds was transferred to the accounts of the National Bank of Poland. In the same period, Poland paid EUR 38.7 billion to the EU, which results in the net balance of EUR 83.57 billion (see Nurzyńska 2016) 
more in Russia and Romania (4.4\% and 4.8\%, respectively) (CIA database), enjoying a different position in the social and economic space. Romanian agriculture accounts for $28.3 \%$ of the total employment, while in Poland for $12.6 \%$. In this respect, Russia is the least "agricultural" of the analysed countries, as its agricultural sector provides jobs to only one tenth $(9.4 \%)$ of the employed (Figure 1).

Figure 1. Labour force - by sector of economy

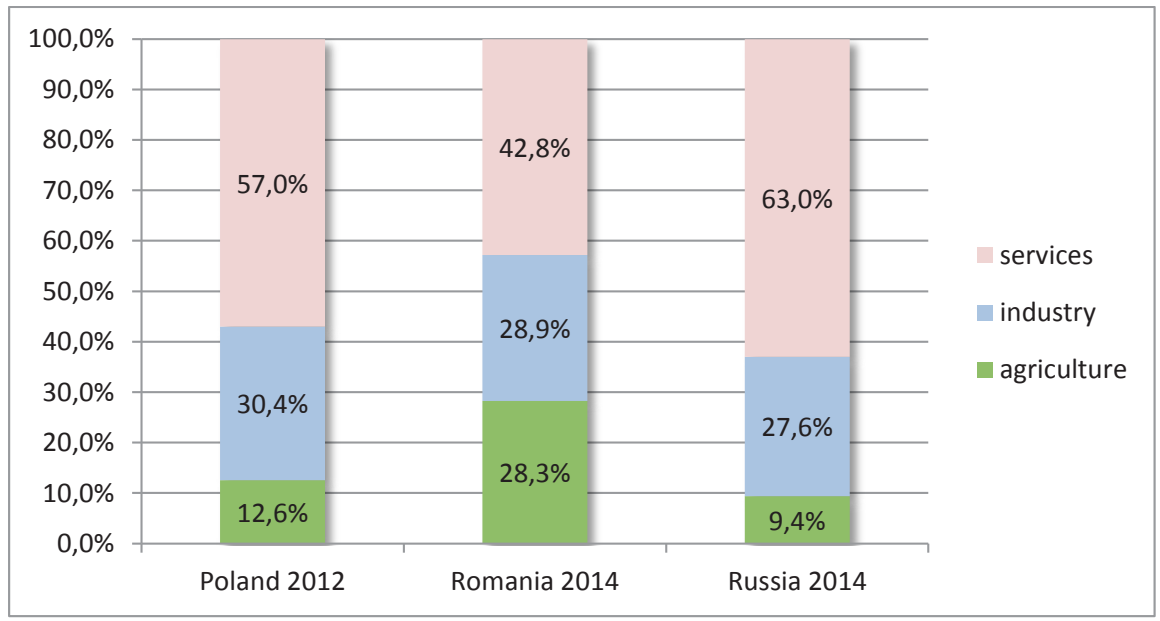

Source: CIA database.

Regardless of differences, a significant percentage of the population in post-communist countries still lives in the countryside (rural areas). In this sense, Russia with only $26 \%$ of citizens living in the country is the least rural country. In Poland and Romania, this percentage amounts to $39.4 \%$ and $46.1 \%$, respectively. For Russia and Romania, these ratios have been slowly but systematically decreasing, whereas in Poland the population in rural areas has been growing steadily since 2000 (UN 2014). 
Figure 2. Rural population (\% of total) $)^{5}$
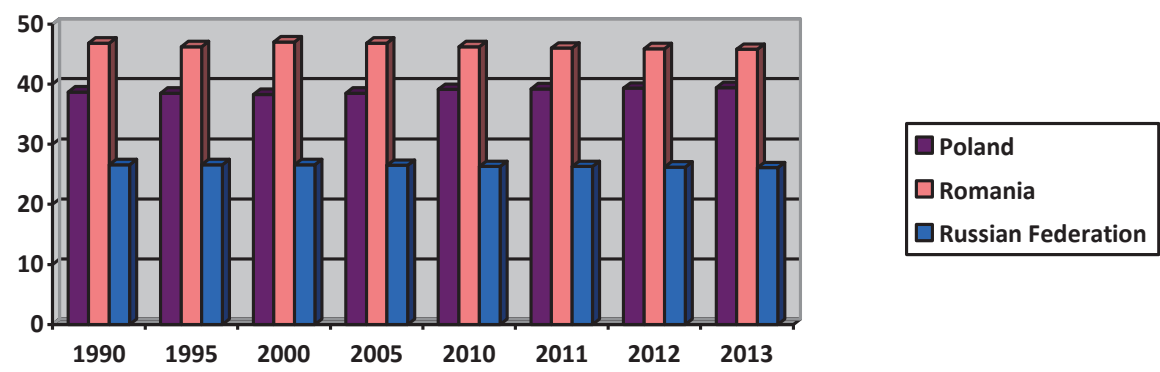

Source: http://data.worldbank.org/indicator/SP.URB.TOTL.IN.ZS

Both in Russia and Romania, the percentage of children and young people living in the country is slightly higher than in the city, while that of young adults is lower. This basically results from young people's migration to the city. With the countryside generally perceived as a positive place with plenty of life choices, Poland is an exception. In Russia, in 2002-2010, the number of the population in rural areas fell by 1.2 million, whereby most of those leaving are young people (due to unemployment, lack of good job offers and life prospects) (Mukhanova 2014: 127). A similar trend is observed in Romania, although here the countryside often becomes a place of refuge for those who have not succeeded in the city (Tudor 2014; Catrina 2015).

As regards life prospects in post-communist countries, significant differences, both objective and subjective, may be observed between the countryside and the city. Generally, the countryside (particularly agriculture) is not considered to be a place offering good options for future life. However, it begins to be perceived as such by those who leave school prematurely or graduate from less renowned schools (negative motivation), or conversely, who recognise the countryside for its positive qualities, such as immediate access to nature, healthy lifestyle, professional self-fulfilment (positive motivation). Among the analysed countries, only Poland has managed to break the stereotype of the countryside as a lagging, underdeveloped region, limited to agriculture, offering no additional values (CBOS 2014).

5 Urban population refers to people living in urban areas as defined by national statistical offices. It is calculated using World Bank population estimates and urban ratios from the United Nations World Urbanisation Prospects. 
Nevertheless, regardless of the country, young people from rural areas generally plan their future life away from the countryside. They are aware of the risks involved, particularly of those related to the labour market. Nowadays, these risks are present both in developed and developing postcommunist countries, where unemployment together with precarious forms of work have become a natural element of social landscape, right next to job insecurity. Education seems to be perceived as a universal panacea to all these problems by the youth living in the countryside.

\section{From education to employment - preparation and barriers}

In all the analysed countries, the aspirations of young people in terms of their educational development are high. They may be observed both at the declarative level and in the actual decisions and educational choices. In European countries, a significant increase in this respect was observed in 20052010 , i.e. until the saturation of the labour market with people with higher education, followed by the simultaneous drop in the numbers of students due to demographic decline. The rise in educational aspirations at that time was recorded particularly in Poland, where in 2009, as many as $91 \%$ of Poles believed that education was the ultimate goal, with $85 \%$ of adults wanting higher education for their children (CBOS 2009). Studies conducted after 2010 point to the evident cooling of educational aspirations among young people in many countries. This is visible both in opinion polls and educational choices. In Poland, the number of people who believed in education dropped by $9 \%$ between 2009 and 2013 (from 91\% to 82\%) (CBOS 2013). Repeated studies of educational trends among young people, conducted in Poland over the period of 2002-2015, reveal the same tendency. In the light of academic inflation and market saturation with people with higher education, young people's educational aspirations started to decrease. This trend is primarily driven by the drop in educational aspirations of young people from families whose social and economic status is either low or medium, i.e. mainly those from rural areas. At the same time, the educational aspirations of young people with a high-status background are on the rise, which may be observed both in rural and urban areas (Domalewski 2016, Wasielewski 2012). Russian studies show that the first decade of changes in education after the dissolution of the Soviet Union had a negative effect on educational 
aspirations of young people from minority groups (living primarily in rural and peripheral areas), and consequently, on their educational choices and career opportunities (Prokhorova 2007). To a large extent, this was caused by a major economic recession which has destroyed much of the cultural and educational infrastructure in rural areas (Kalugina 2004).

Regardless of these adjustments, higher education is still on demand among young people in Poland, Russia and Romania, and it is (primarily) motivated by the need to find a well-paid and prestigious job (irrespective of the place of residence or social status). This is also the major factor behind parents' motivation to invest in their children's education and thus give them a chance to gain a better social and material position. The vision of difficulties in pursuing these educational aspirations would be a cause for concern for $54.7 \%$ of parents in Russia, $49.1 \%$ in Romania and slightly fewer $(40.8 \%)$ in Poland (WVS 2011-2013). Education ensures better life options for young people in Russia, which is mainly verified by the labour market. A study conducted in 2014 shows that over three quarters (77.9\%) of secondary school graduates consider higher education as essential for them to succeed in life. This opinion is shared by $70.5 \%$ of those in colleges which in fact are profiled institutions of secondary education specialising in preparing young people for semi-professions. However, even for those in vocational schools, i.e. schools which educate qualified employees for industry, agriculture and services sector, this figure was $43.1 \%$ (Konstantinovskiy \& Popova 2015). This way of thinking among young people depends strongly on their social origins, place of residence and their choice of educational trajectories. "Worse" educational trajectories seem to be driven by an accumulation of unfavourable conditions which include low social status, ethnic minority background and living in rural or peripheral areas (Konstantinovskiy 2012). In the light of these tendencies, it is not surprising that non-typical forms of education are very popular among marginalised groups (e.g. young people from rural areas). They typically include remote education (where the number of students increased 11-fold, from 61,000 in 1990 to 672,000 in 2010) and the so-called post-matura education (mostly colleges). The both forms of education, to a large degree, account for an increase in higher education rates in Russia.

Undoubtedly, education has grown to be a fundamental value and a pillar of rural youth's life strategies, reflected not only in higher educational aspirations, but also in higher education rates. The range of this universal 
trend has been different in different countries, and depending on their starting point (and local conditions) it has produced different social effects. Major educational progress has been observed among the least skilled in Russia and Romania. According to statistical data for these two countries, the proportion of uneducated people aged over 25 has reduced. The changes in this area are related to increased educational aspirations of younger generations (particularly in rural and peripheral areas), development of systems of higher education and generational changes in the structure of education (older generations are replaced by the younger, better educated ones).

Increased rates of education among post-communist societies are particularly evident for secondary and higher education. Over the period of only 20 years (between 1990 and 2010), the percentage of people with this level of education rose by $31.2 \%$ in Poland, $17.2 \%$ in Romania, and $16.7 \%$ in Russia. Particularly interesting is the rapid increase in the number of people with higher education (see World Bank Education Statistics), especially when analysed through the prism of generational changes. The comparison of the education rates in two age groups, i.e. people aged 25-29 and 60-64, reveals the scale of these changes and people's general tendency to shift from traditional, rural ways of living to those typical of open, urban communities. The reasons for these trends are relatively universal. They include as follows: the aforementioned high level of educational and vocational aspirations among young people, pressure to acquire the qualifications necessary in the labour market, and opening of education systems to young people from thus far marginalised groups (e.g. of lower social status or from rural areas), to a large extent inspired by the privatisation of higher education in most postcommunist countries (OECD 2015).

In this respect, the transformation of the political system in this countries has resulted in increased educational (and social) opportunities for young people. As many as $44 \%$ of young Russians and 36\% of Poles aged 25-34, have obtained their diploma of higher education (see OECD 2015:86). However, it needs to be remembered that it is mostly their families who pay for their education and educational success. Investments in education have been one of the main expenses of household budgets, both in the countryside and in the city, while a wide offer of non-state schools, established under the new law, has turned out to be a chance (mostly due to less stringent enrolment criteria) for young people from poorer families. This is especially visible in rural areas. In Poland, most students of non-state 
schools of higher education are rural youth, despite their families' limited budgets and other expenses. Importantly enough, 30\% of the rural youth who obtains higher education return to the countryside. Additionally, the countryside is nowadays also populated by young people of non-rural origin (Wasielewski 2013). Consequently, the structure of education in the population of young people in Polish rural areas (aged 25-29) looks much better than in the 1990s, with $26.2 \%$ of them having diplomas of higher education, $36.7 \%$ - secondary and post-secondary, $34.1 \%$ - basic vocational, and $7.4 \%$ - primary education (NSP 2011).

Russia has also experienced its educational boom which has resulted in improved structure of education among rural youth. Generally, complete secondary education, either general or vocational, has been obtained by the majority of people. After the illusion of the 1990s, when it was generally believed that no higher education was necessary to make a career, a dynamic increase was observed in educational aspirations of young people. Since 2000, they seem to have been able to better understand how the labour market changes and draw conclusions for themselves. By 2010, the number of students in Russia grew over 2.5 times. However, the participation of rural youth in these changes is smaller than that of their peers from the city. In 19942011, the number of young people (aged 15-30) with complete secondary education fell from over $50 \%$ to below $40 \%$ in rural areas. At the same time, the proportion of young people dropping out of school before completing their secondary education and taking up other forms of vocational training (people aged 15-22) increased from $23 \%$ to $37.2 \%$. The percentage of rural adolescents entering higher education also went up from $11 \%$ in 1994 to $18.4 \%$ in 2011 . However, this may not seem to be a great achievement considering the wide offer of non-state schools and that $64 \%$ of adolescents aged 15 , and $78 \%$ of young people aged $20-24$, declare that they want to go to university (Mukhanova 2014: 131-134). Importantly enough, even those who do take up studies generally end up settling down in cities which give them a chance for social advancement. Russian studies show that only $3 \%$ of graduates return to the countryside (Mukhanova 2014:134).

The situation is different in Romania, where people attend school just for the sake of attending school, and where, for a variety of reasons (ethnic, cultural, high cost of education, poor absorption of labour markets), young people not only do not aspire to higher education, but also drop out of school significantly more often before completing their education. In Romania, the 
average rate of early school leavers is $19.1 \%$ (Eurostat 2015), and $27.7 \%$ for rural youth ${ }^{6}$. The secondary school completion rate is much lower in rural areas $(71.4 \%)$ than in the city $(94.7 \%)$. This is caused not only by the poor economic situation and low cultural capital of rural families, but also by the poor condition of the education system in rural areas and limited access to secondary schools (most of them are located in cities and therefore too expensive). As a result, rural youth most often opts for vocational schools, i.e. schools with a very low prestige in Romania (widely considered to be intended for "educational losers"), accounting for $2 / 3$ of their students. The interest in completing secondary and higher education has dropped significantly - by approximately $10 \%$ over the last few years. In 2012, rural youth accounted for only $24 \%$ of all university students (Balica 2014). As many as $62 \%$ of the youngest countryside residents (aged 15-24) have primary education only, compared with $42 \%$ in the population aged $25-34$, and $32 \%$ in the population aged 35-49 (Tudor 2014). As regards access to education and educational trajectories, significant differences may still be observed between different regions, as well as rural and urban areas. Metropolis and large city citizens are the most privileged population in this respect. Inhabitants of Bucharest are evidently more likely to study, while young people in Transylvania generally choose vocational schools. Differences between the city and countryside may also be observed in terms of private tuition/private lessons. These are clearly more popular among city dwellers (10.7\%) than in rural areas $(3.7 \%)$, which further contributes to inequality of their educational opportunities (see Umbreş et al. 2014: 66-72).

As may therefore be seen, while the system transformation might have brought institutional changes and affected young people's aspirations in terms of their education, social status, motivation for learning, and educational and professional preferences, it has never transformed the basic selection mechanisms responsible for educational choices. The level of educational inequality (measured by the distribution of years in education) is similar in all post-communist countries. Of those analysed here, it is the highest in Poland and Romania, and the lowest in Russia (see Human Development Index). At the same time, the PISA studies (measuring school pupils' scholastic performance) show that the percentage of resilient students, i.e. pupils who

6 In contrast, the rate of early school leavers in Poland is 3.8\%, and in rural areas it is $6.1 \%$ (and it tends to decrease). 
come from disadvantaged backgrounds (low socioeconomic status, rural origins), yet exhibit high levels of school success (measured by the PISA tests), is the highest in Poland (8.4\%), while in Russia it is $5.2 \%$ and in Romania only $2.8 \%$. On the one hand, this indicator reveals the systemic quality of school education which allows to overcome class differences (and thus not to waste talents of children from socially disadvantaged backgrounds), while on the other hand, it points to the relatively egalitarian nature of the education system whose open structure gives a real chance for social advancement through education (OECD 2013).

Regardless of the effort invested, a large number of the young people from post-communist countries who opt for education (higher education) end up being disappointed. The diploma, which was supposed to be a guarantee of job security and social advancement, particularly important for rural youth, is proving to be increasingly insufficient. Employment opportunities for people with high formal qualifications are limited due to the difficult situation of post-socialist economies, but also due to inadequate educational offer which does not correspond to the labour market needs, and due to people's exaggerated belief in the power of the diploma (credentialism). This is demonstrated primarily by young people from families with no traditions of investing in higher education, preferring easily accessible schools which follow lower standards and offer easy-to-acquire, but practically worthless diplomas. Non-state institutions of higher education, which have developed their networks in all post-communist countries, have paradoxically turned into an offer addressed mainly to young people from poorer, i.e. also rural, families. In all the countries, people complain about poor effects of their work. State schools are also more and more heavily criticised, as they find it difficult to adjust to the new reality and define their own role. Similar problems are faced by the sector of vocational education and vocational training courses. The career counselling system (educational and professional coaching) is ineffective despite its importance in the times of unpredictable labour market conditions, particularly for young people who, knowing nothing about themselves, social needs and future trends, often make ill-considered choices. This is not so much the case of young people in the city, especially those from rich families, whose educational strategies are carefully thought out and planned from early on. Nevertheless, in post-communist countries, both in rural and urban areas, investments in education have a generally more compulsive character than in the West. 


\section{Entering the labour market and employment}

Transition from education to employment is defined as a period in which young people should "theoretically" complete their formal education, find a job that matches their qualifications and gain financial independence ${ }^{7}$. In reality, there are many different career paths. Studies are combined with parttime jobs, whereby formal education is replaced or supplemented with training courses, internships and coaching. These new solutions prolong the moment of the actual transition, turning it into a sequential process. Continuation of studies, taking up family responsibilities in the meantime, educational breaks and stalling, etc. are nowadays generally popular strategies in all countries. They are also common in post-communist states, whereby major differences may be observed between the European and Asian ones.

In Europe, transition from education to employment is getting delayed, as the whole process becomes more complicated and takes a longer time. Different paths of transition, related either to long (typically due to acquiring professional experience) or short education process (which does not bring the desired qualifications), trigger different types of problems. The former is responsible for overeducation and contributes to underemployment. Conversely, the latter causes undereducation, where the level of qualifications and education is insufficient for the current market needs, which in turn results in constant balancing between temporary forms of employment (in the sector of informal employment or grey market) and unemployment. Studies carried out in Central and Eastern Europe show that overeducation is more prevalent than unemployment among university graduates. This problem is present in every (post-)communist country, with rural youth taking up this path more and more often (Ilieva-Trichkova, Boyadjieva 2014). According

The following stages of transition have been defined: "A young person who has 'transited' (completed their labour market transition) is defined as one who is currently employed in (i) a stable and satisfactory job, (ii) a stable but non-satisfactory job, (iii) a satisfactory but temporary job, or (iv) is self-employed and satisfied with their job. A young person is considered 'in transition' if he or she is either (i) currently unemployed (relaxed definition), (ii) currently employed in a temporary or non-satisfactory job, (iii) currently self-employed and unsatisfied, or (iv) currently inactive and not in school, with the intention of looking for work later. A young person who has 'not yet transited' is one who is either still in school (inactive students) or currently inactive and not in school (with no intention of looking for work)" (ILO 2015b: 28). 
to the School-to-Work Transition Survey (SWTS), it is particularly evident in Russia, where young people from the city are more likely to have a stable employment or a satisfactory temporary job than rural youth who tend to be economically less active or prefer to continue their studies in the city (ILO 2015b: 57-58).

Agriculture, which still at the end of the $20^{\text {th }}$ century would incorporate any extra labour force and thus provide an alternative to (official) unemployment, today is no longer an option even for rural youth. In Poland, the agricultural sector employs less than $8 \%$ of the young workforce, in Romania over $22 \%{ }^{8}$. In Russia, it is at the level of $15 \%{ }^{9}$, which constitutes a dramatic drop over the last 12 years - the average annual outflow of young people from agriculture is estimated at 400,000 , and it significantly exceeds the average for the total population leaving this sector (Mukhanova 2014: 129).

In the analysed countries, the percentage of people active in the labour market is higher for rural youth (by several to a dozen or so of percentage points). This may be due to three reasons: firstly, lack of optimal conditions to continue education; secondly, high demand for unqualified labour force; and thirdly, due to financial pressure (one's own or from the family). The causes are not mutually exclusive; in some cases they can accumulate, making it even more difficult to find a decent job.

8 Own calculations based on the EUROSTAT data. It is worth mentioning that despite differences across European countries (e.g. the already quoted high proportion of young people working in agriculture in Romania), the average rate for the European Union is $3.4 \%$. This points to large discrepancies in the employment structure between Western Europe and post-communist countries. Once again, a big disparity may be noticed between the high proportion of young people working in agriculture and the role this sector plays for the Romanian economy. Based solely on this observation, it may be assumed that the conditions of work in Romanian rural areas may differ from what young people would imagine as decent work.

9 Global Employment Trends for Youth (ILO 2015). 
Figure 4. Labour force participation rate by age (15-24) and area of residence in \% (2015)

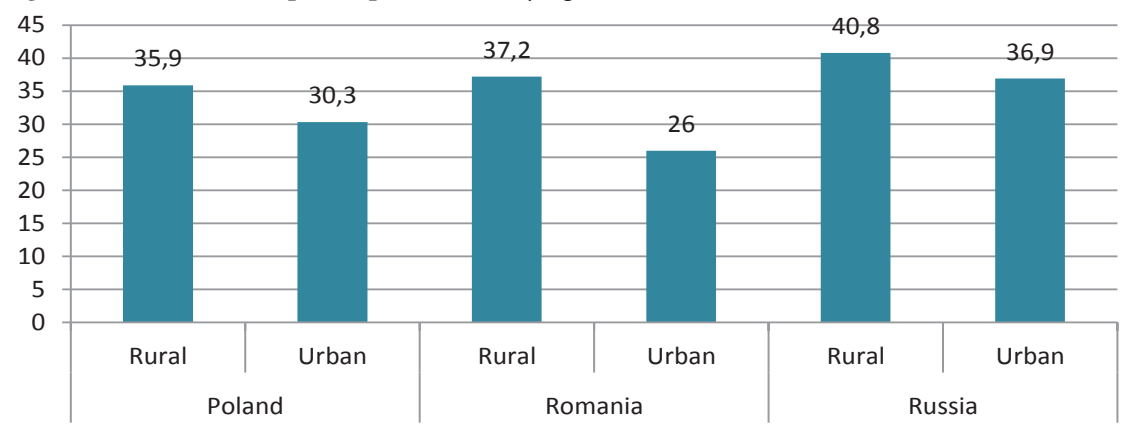

Source: Ilostat database

In countries with traditional agriculture and limited absorption power of urban labour markets, the rates of official unemployment among youth in rural areas are lower than in cities. Farms provide protection to young people, offering them a relatively safe harbour where they can wait through rough times. This is for example the case of Romania (Figure 5). In countries whose countryside is not primarily agricultural in character and where work in agriculture does not seem to be an alternative (as such is sought in other, non-rural markets), unemployment rates among young people are higher (Poland, Russia).

Figure 5. Unemployment rate by age and rural / urban areas in \% (2015)

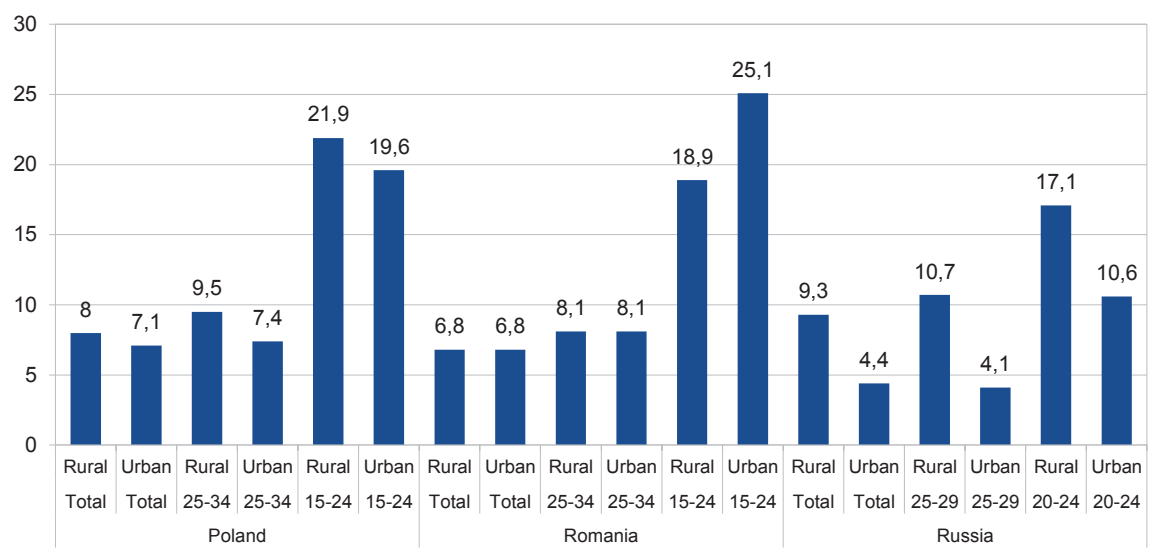

Source: ILOSTAT database, Mukhanova 2014: 130 .

10 The data presented for Russia comes from April 2013. "Total" refers to the population aged $15-72$. 
The problems of unemployment and shrinking workforce resources are further exacerbated by the increasing numbers of economically inactive people. Unlike unemployment, economic inactivity may result not only from objective but also from subjective reasons. Young people who fall within this category has been collectively referred to as NEETs (the acronym from Not in Education, Employment, or Training). Rates of NEETs show the percentage of young people who are at risk of being permanently excluded from the labour market. According to our analyses, the high and relatively stable representation of NEETs is typical of all post-communist countries (Figure 6), with their numbers being generally higher in rural areas, as revealed by our detailed (local) analyses.

Figure 6. Participation of young people aged 15-24 in the category of NEETs

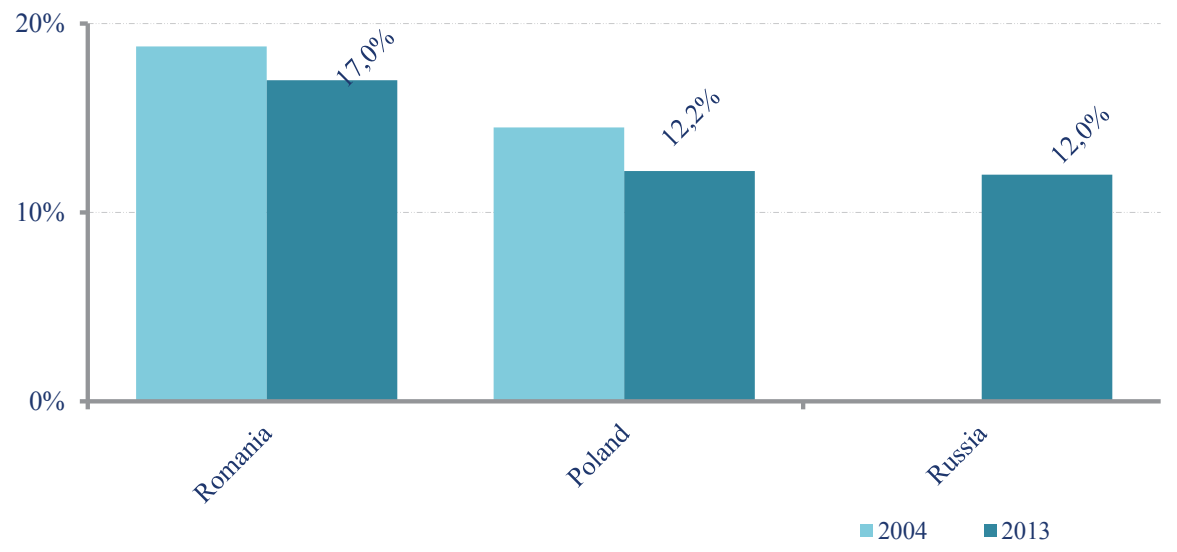

Source: Own materials based on the ILOSTAT database.

Worse conditions on rural labour markets force young people towards non-standard forms of employment. Most frequently, they opt for the sector of informal employment. This strategy is particularly widespread in Russia, where in $2011,40 \%$ of young people aged $15-24$ and $30 \%$ of those aged $25-$ 29 , were in informal employment (compared with $24 \%$ in older cohorts). For $33 \%$ of young people, this sector was the main place of employment (and probably the main source of income). In rural areas, $87 \%$ of young people work in the informal sector - these are mainly people with incomplete secondary education (Mukhanova 2014: 144-145). 


\section{Conclusions}

Transition from education to satisfactory employment, which today takes up nearly the entire third decade of young people's life, is just an external manifestation of changes that occur in labour markets around the world. In post-communist countries, the burden and risks related to this process (unemployment, together with its new, post-modern variant, i.e. variable, pluralistic forms of part-time, temporary forms of employment) are borne by people rather than institutions. Based on the analyses conducted by us under the international project of nine post-communist countries, we have asked how rural youth manages in the face of these changes? What are their transition paths (from education to employment), and what is their place in the social structure enforced on them by the reality of their country's political transformation?

In developed European countries, changes in the labour market result in a different (more pragmatic) approach to education, translate into more refined educational strategies and prolong the time spent in education. In post-communist countries, a similar response may be observed, but more rigid and compulsive in character, particularly visible in populations in which investing in education never was a cultural norm. The difference is perfectly illustrated by representatives of lower social classes (including rural youth) and their faith in the power of the academic diploma (regardless of its quality). In post-communist countries, it is a common practice among such youth to enrol at easily accessible schools and universities, where requirements for students are not very high. These are typically non-state institutions of education which started appearing in every post-communist country after the political transformation. By graduating from them, young people might be given a chance for social promotion, but at the same time they need to remember that they are at a greater risk of worse job offers and possible longer experimentation with different professional functions, which in consequence may not provide for a satisfactory career path.

However, most of rural youth do not go to universities. They finish their education at a very low level, drop out of school prematurely (typical of Romania) or opt for vocational education (as in Russia or Poland). Entering the labour market is even more difficult in the case of these education paths. In all the post-communist countries analysed in the article, the countryside generally loses to the city and the opportunities that the city offers to young 
people. This process is, on the one hand, further driven by the culture of consumerism (brought to rural youth by modern media), and on the other hand, by the aftermath of the system transformation and insufficient modernisation of the agriculture, and rural sector in general. The cases presented in the article reveal certain similarities, but they point to even more differences resulting from the specific character of systemic changes in the respective countries, subsidies available to agriculture and rural areas, and competitive offer of the city. In Russia and Romania, the desire to leave the countryside is very strong among young people, but effective migration turns out to be possible only for some of them (despite the invested funds). In Romania, young people tend to return to the countryside (due to their negative experience of economic migration). Among the countries subject to the analysis, Poland is the only one in which the new educational offer and all the aspects of rural life are viewed so positively, on a scale unmatched by any other country. Nevertheless, even here young people believe that better life opportunities can be found in the city, which is where they take part in the competition for a better employment.

\section{References}

Balica, M. 2014 Rural-urban disparities in education - Romania, materials (pptx presentation) from the Polish-Romanian seminar organised in October 2014 by the Institute of Agriculture at the Romanian Academy, Bucharest.

Catrina, S. 2015 Lines of division and threats of social cohesion - towards the question on the role of youth in transition processes and social changes, materials (pptx presentation) from the international seminar organised under the NCN project in Sopot in May 2015.

CBOS 2009 'Aspiracje i motywacje edukacyjne Polaków w latach 1993-2009. Komunikat z badan' (Educational aspirations and motivations of Poles in 19932009. Research Communication), BS/70/2009, Warsaw: CBOS.

CBOS 2013 'Wykształcenie ma znaczenie? Komunikat z badan' (Is education significant? Research Report), BS/96/2013, Warsaw: CBOS.

CBOS 2014 'Wieś polska - stereotypy, Komunikat z badań' (Polish countryside stereotypes. Research Communication). BS/4/2014. Warsaw: CBOS.

CIA database, The world fact book. Available: https://www.cia.gov/library/ publications/the-world-factbook/ (14.08.2016). 
Domalewski, J. 2016 Strategie życiowe młodzieży ponadgimnazjalnej (Life strategies of upper secondary school youth), a research report under the NCN project "Młodzież w krajach (post)komunistycznych - potencjał innowacyjny, nowe konteksty, nowe problemy i nowe wyzwania" ("Young people in (post-) communist countries - innovative potential, new contexts, new problems and new challenges" (Agreement with the NCN No UMO-2013/08/M/HS6/00430), a typescript.

EUROSTAT database. Available: http://ec.europa.eu/eurostat/data/database (14.08.2016).

http://farmsubsidy.openspending.org.

Illieva-Trichkova, P., Boyadjieva, P. 2014 'Dynamics of inequalities in access to higher education: Bulgaria in a comparative perspective, European Journal of Higher Education 4(2): 97-117.

ILO 2015a. Global Employment Trends for Youth 2015. Intl Labour Organisation.

ILO 2015b. Work4Youth Publication Series No. 29, Youth and rural development: Evidence from 25 school-to-work transition surveys.

ILOSTAT database. Available: www.ilo.org/ilostat/faces/help_home/data_by_subject (14.08.2016).

Kalugina, Z. 2004 'The Rural Labour Market in present-day Russia', Eastern European Countryside 2.

Knieć, W. 2012 Wspólna Polityka Rolna a zrównoważony rozwój obszarów wiejskich Polski: analiza socjologiczna (The Common Agricultural Policy and sustainable rural development in Poland: A sociological analysis) The Publishing Office of the Nicolaus Copernicus University in Torun.

Konstantinovskiy, D. L. 2012 'Social inequality and access to higher education in Russia, European Journal of Education 47(1), pp. 9-24.

Konstantinovskiy, D. L. \& Popova, E. S. 2015 'Youth, labor market and expansion of higher education'. Sociological Studies (Sociologicheskie issledovaniia) 11:37-48.

Mukhanova, M. 2014 'Rural Youth in Russia: Their Status and Prospects for Development', Eastern European Countryside 20(1).

NSP 2011 2011. Ludność. Stan i struktura demograficzno-społeczna (Population. Its state and demographic and social structure). Available: http://stat.gov. $\mathrm{pl} /$ spisy-powszechne/nsp-2011/nsp-2011-wyniki/ludnosc-stan-i-strukturademograficzno-spoleczna-nsp-2011,16,1.html

Nurzyńska, I. 2016 Polska wieś i rolnictwo jako beneficjenci funduszy Unii Europejskiej (Polish countryside and agriculture as beneficiaries of the European Union funds) in: J. Wilkin, I. Nurzyńska (ed.) Polska wieś 2016. Raport o stanie wsi (Polish countryside 2016. Status report), Warsaw 2016: FDPA.

OECD 2013. PISA 2012 Results: Excellence Through Equity: Giving Every Student the Chance to Succeed (Volume II), Paris: OECD Publishing. 
OECD 2015. Education at a Glance 2015: OECD Indicators, OECD Publishing. Available: http://dx.doi.org/10.1787/eag-2015-en

Prokhorova, O. G. 2007 'The Upbringing of Children Under the Conditions of the Extreme North', Russian Education and Society 49(1).

Szafraniec, K. 2001 Wartość wykształcenia na wsi - fakty, tendencje, konsekwencje (The value of education in the country - facts, trends, consequences), in: I. Bukraba-Rylska \& A. Rosner (eds) Wieś i rolnictwo na przełomie wieków (The countrywide and agriculture at the turn of centuries), Warsaw: IRWiR PAN.

Szafraniec, K., Domalewski, J., Szymborski, P., Wasielewski, K. \& Wernerowicz, M. 2017 Generation in Post-collectivist Space. Dilemmas during the Time of Transition, Geneva: Peter Lang International Publishing House (forthcoming).

Tudor, M. 2014 Romanian rural youth - socio-economic resilience factor, materials (pptx presentation) from the international scientific conference: "Młodzież w gospodarstwach rodzinnych i na obszarach wiejskich Europy" ("Young people in family-run agricultural holdings and rural areas in Europe") organised on 4-5 July 2014 by the Agricultural University of Kraków.

Umbreş, R., Sandu, D. \& Stoica, C.A. 2014 Romanian Youth: concerns, aspirations, attitudes and life style. Research report by the Center for Urban and Regional Sociology - CURS for Friedrich-Ebert-Stiftung Romania (FES).

UN, 2006 Guide to the implementation of the World Programme of Action for Youth, New York.

UN, Demographic Yearbook 2014, accessed at: http://unstats.un.org/unsd/ demographic/products/dyb/dyb2.htm (14.08.2016).

Wasielewski, K. 2012 Zmiany poziomu aspiracji edukacyjnych młodzieży jako efekt adaptacji do nowych warunków społeczno-ekonomicznych (Changes in the educational aspirations of young people as a result of adaptation to new social and economic conditions), in: M. Zahorska (ed.) Zawirowania systemu edukacji. Z perspektywy socjologicznych warsztatów badawczych (Education system in revolution. From the perspective of sociological research), Warsaw: UW Publishing, pp. 72-84.

Wasielewski, K. 2013 Młodzież wiejska na uniwersytecie - droga na studia, mechanizmy alokacji, postawy wobec kształcenia (Rural youth at university path to studies, allocation mechanisms, attitudes towards education). Toruń: Wydawnictwo Naukowe UMK / UMK Publishing Office.

Wilkin, J. 2007 Czy paradygmat wielofunkcyjnego rolnictwa zrewolucjonizuje europejską politykę rolną? Podsumowanie badań i wnioski praktyczne (Will the paradigm of multifunctional agriculture revolutionise the European policy of agriculture? A summary of research and practical conclusions), in: J. Wilkin (ed.) Wielofunkcyjność rolnictwa. Kierunki badań, podstawy metodologiczne 
i implikacje praktyczne (Multifunctionality of agriculture. Research directions, methodological basis and practical implications), Warsaw: IRWiR PAN.

World Bank. Education Statistics. R. J. Barro \& Jong-Wha Lee. Available: http://www. barrolee.com/).

World Bank 2015. World Development Indicators. Available: http://databank. worldbank.org/data/reports.aspx? source $=2 \&$ country=\&series=SE.PRM.CMPT. ZS\&period.

World Value Survey Database. Available: http://www.worldvaluessurvey.org/ WVSDocumentationWVL.jsp. 